\title{
Fatty Acids Profile, Trans Isomers, and Lipid Quality Indices in Smoked and Unsmoked Cheeses and Cheese-Like Products
}

\author{
Beata Paszczyk *, Magdalena Polak-Śliwińska® and Joanna Łuczyńska® \\ Faculty of Food Sciences, University of Warmia and Mazury in Olsztyn, 10-719 Olsztyn, Poland; \\ m.polak@uwm.edu.pl (M.P.-Ś.); jlucz@uwm.edu.pl (J.Ł.) \\ * Correspondence: paszczyk@uwm.edu.pl; Tel.: +48-89-523-36-81
}

Received: 4 November 2019; Accepted: 18 December 2019; Published: 20 December 2019

\begin{abstract}
The purpose of this study was to evaluate the fatty acid composition, including trans C18:1 and C18:2 isomers and the content of conjugated linoleic acid cis9trans11 C18:2 (CLA), in commercial smoked and unsmoked cheeses and cheese-like products available on the Polish market as well as to compare lipid quality indices in these products. The composition of fatty acids was determined with the gas chromatography method. The conducted study demonstrated that smoked and unsmoked cheeses as well as smoked and unsmoked cheese-like products were characterized by various contents of fatty acids and various lipid quality indices. The smoked and the unsmoked cheeses had significantly higher $(p<0.05)$ contents of saturated fatty acids (SFA), short-chain fatty acids (SCFA), and branched-chain fatty acids (BCFA) than the smoked and the unsmoked cheese-like products. The monounsaturated fatty acids (MUFA) and the polyunsaturated fatty acids (PUFA) contents were the highest in unsmoked cheese-like products ( $39.29 \pm 1.49 \%$ and $9.13 \pm 0.33 \%$, respectively). In smoked and unsmoked cheeses, MUFA were above $24 \%$ and PUFA were above $2.4 \%$. The total content of trans C18:1 isomers was significantly higher $(p<0.05)$ in the cheeses, but in the group of these isomers, trans $10+$ trans 11 isomers were dominant. High levels of trans6-trans 9 isomers (up to $2.92 \%$ of total fatty acid) were found in some of the samples of unsmoked cheese-like products, while their content in cheeses was lower. The lipid quality indices in cheeses and cheese-like products were varied. The smoked and the unsmoked cheeses were characterized by significantly higher $(p<0.05)$ values of the index of thrombogenicity (TI) and atherogenicity (AI) indices and significantly lower $(p<0.05)$ values of the hypocholesterolemic/hypercholesterolemic $(\mathrm{HH})$ ratio.
\end{abstract}

Keywords: cheese; cheese-like products; fatty acids; trans isomers; lipid quality indices

\section{Introduction}

All natural fats and oils are a combination of monounsaturated, polyunsaturated, and saturated fatty acids. A characteristic feature of milk fat is the presence of saturated fatty acids (SFA) as well as a high content of short-chain fatty acids (SCFA). Typical milk fat from dairy cows contains about $70 \%$ of SFA, $25 \%$ of monounsaturated fatty acids (MUFA), and about $5 \%$ of polyunsaturated fatty acids (PUFA) [1]. Of the saturated fatty acids, about 10\% are short-chain fatty acids (C4:0-C10:0) [2]. Studies on fatty acid effects on human health indicate that only a few individual fatty acids are responsible for the negative consequences on consumer health $[3,4]$. According to Ulbricht and Southgate, acids such as lauric (C12:0), myristic (C14:0), and palmitic (C16:0) acid are highly related to an increased risk of atherosclerosis, obesity, and coronary heart diseases [5]. Studies of other authors assessing the impact of saturated fat intake on metabolic health are inconclusive [6] and indicate that the physiological impact of dietary SFA depends not only on dietary source and food matrix but also on SFA type 
and composition $[7,8]$. In milk fat, SFAs are the predominant class of fatty acids (FA), but these fats are unique as they also comprise a wide and complex variety of SFA, including short-chain fatty acids, medium and long-chain fatty acids, as well as odd and branched-chain fatty acids [2,9]. Studies by Kim and Je [10] have shown that the consumption of dairy products may reduce the risk of metabolic diseases. Unsaturated fatty acids (UFAs) are usually called "healthy fats", especially for their impact on the level of cholesterol in blood [11,12]. PUFAs decrease cholesterol content more strongly than monounsaturated fatty acids (MUFAs) [13]. n-3 PUFA prevents heart disease and improves immune response. Oleic acid (cis9 C18:1) and linolenic acid (cis9cis12cis15 C18:3) have anti-cancer and anti-atherogenic properties $[11,13] . n-6$ PUFA improves sensitivity to insulin and thus reduces the incidence of type 2 diabetes [12].

Trans fatty acids (TFAs) are unsaturated fatty acids that contain at least one double bond in the trans configuration. Trans fats are found in foods originating from ruminant animals and in foods containing partially hydrogenated vegetable oils (PHVO). The levels of natural trans isomers in milk and meat ruminant animals can comprise up to $6 \%$ of the total content of fatty acids, and industrial trans fat levels can comprise up to $60 \%$ of the total content of fatty acids. The TFA content of partially hydrogenated vegetable oils (PHVO) depends on the variables of the hydrogenation process, e.g., time, catalyst, temperature, hydrogen pressure, and types and proportions of oils and composition of fatty acids. The primary dietary TFAs are vaccenic (trans11 C18:1) and elaidic acid (trans9 C18:1). Vaccenic acid is the major ruminant TFA, whereas elaidic acid is the main TFA isomer in industrial hydrogenation [14]. According to literature data, some fatty acids with trans configuration have an adverse effect on human health $[15,16]$. Epidemiological studies have shown a direct association between the intake of TFA and the risk of coronary heart disease (CHD), primarily accounted for by industrially produced TFA [17-21].

In its composition, milk fat contains bioactive components that have an impact on human health such as branched-chain fatty acids (BCFA), trans vaccenic acid (trans 11 C18:1), and conjugated linoleic acid cis9trans11 C18:2 (CLA), which are characteristic constituents of milk fat. Branched-chain fatty acids (BCFA, iso- and anteiso) arise in the rumen, where they are synthesized de novo or metabolized from phytol by rumen microorganisms. BCFA represents about $2 \%$ of fatty acids in cow's milk fat [8]. Conjugated linoleic acid (CLA) is a mixture of geometrical and positional isomers of linoleic acid LA (cis9,cis12 C18:2), which contains a conjugated double bond system and involves a double bond at positions 8 and 10, 9 and 11, and 10 and 12 or 11 and 13 [22]. Conjugated linoleic acid cis9trans11 C18:2 (CLA) has health-positive properties including, e.g., anti-carcinogenic, anti-atherosclerotic, anti-oxidative, and anti-inflammatory effects [23-28]. Experimental studies have shown that trans-vaccenic acid, the main trans $\mathrm{C} 18: 1$ isomer in milk fat, has anti-cancer and anti-atherogenic effects [29].

Cheeses are a significant component of the human diet. The assortment of cheeses on the Polish market is very wide. Cheese is a significant source of fat in the human diet and contains a high variety of fatty acids. Cheese fat currently suffers from an adverse nutritional image, largely due to a perceived association of saturated and trans fatty acids with cardiovascular diseases. Nevertheless, despite the presence of considerable amounts of such fatty acids, there is no clear evidence relating cheese consumption to any disease. Furthermore, cheese contains other fatty acids, e.g., conjugated linoleic acid and oleic acid, which have the potential to improve long-term health. Cheese-like products (or cheese analogues) are usually defined as products made by blending individual components, including non-dairy fats or proteins, to produce a cheese-like product to meet specific requirements. They are being increasingly used due to their cost-effectiveness, which is attributable to the simplicity of their manufacture and the replacement of selected milk ingredients by cheaper vegetable products [30,31].

The smoking of dairy products such as cheese is one of the oldest methods used in the preservation and the production of flavored food. This process provokes important modifications in food composition and sensory attributes. Smoking not only extends the shelf life of food via the effect of dehydration and antioxidant action of the smoke compound, which has the effect on microbial activity, smoking 
also gives special color and flavor to the food. The smoke can be applied to cheese as natural smoke or as a flavoring smoke. The wood, the smoke generation method, and the procedure have a decisive influence on cheese color, smell, taste, and texture as well as on its oxidative stability, microbial growth, and safety. The smoking process significantly enriches the cheese with volatile compounds belonging to a wide variety of chemical families such as: aldehydes (vanillin, furfural, benzaldehyde); furanmethanol; cyclic ketones related to nutty, burnt, coffee, caramel notes [32]; aromatic ketones; furan and pyran derivatives that give pleasant flavors; and nitrogen derivatives, mainly phenol, guaiacol, and syringol derivatives [33,34]. Smoked cheese is appreciated by consumers due to its sensorial properties. However, with the smoking process, there is a risk of the formation of undesired substances such as lipids peroxidation products, which have a significantly important impact on human health. There is a lack of literature data on the impact of smoking on the fatty acids profile in the smoked dairy products. The research by El-Tahra et al. [35] showed that admixing smoke liquid or powder to goat's milk reduced the content of saturated fatty acids and increased the content unsaturated fatty acids of Domiatti cheese. The contents of short and medium-chain fatty acids were lower, and long-chain fatty acids were higher in smoked cheese as compared with control samples.

Therefore, the purpose of this study was to evaluate the fatty acid composition, including trans C18:1 and C18:2 isomers and content of conjugated linoleic acid cis9trans11 C18:2 (CLA) in commercial smoked and unsmoked cow cheeses and cheese-like products available on the Polish market and to compare lipid quality indices in these products.

\section{Materials and Methods}

\subsection{Materials}

The experimental materials were commercial rennet ripening smoked and unsmoked cheese produced with cow milk and commercial smoked and unsmoked cheese-like products available on the Polish market (Table 1). The products originated from various Polish producers and were purchased in stores in Olsztyn in the period from April to May 2018. Each sample was analyzed in duplicate.

Table 1. Analyzed products.

\begin{tabular}{ccc}
\hline Products & $\begin{array}{c}\text { Number of } \\
\text { Samples }\end{array}$ & Producers \\
\hline Smoked cheese & 10 & $\begin{array}{r}\text { SM Mlekpol (four products); Hochland Polska Sp. } \\
\text { z.o.o.; SM Mlekovita (two products); } \\
\text { SM Spomlek, OSM Włoszczowa; OSM Sierpc }\end{array}$ \\
\hline $\begin{array}{c}\text { Smoked cheese-like } \\
\text { products }\end{array}$ & 4 & SM Mlekovita (two products); OSM Giżycko, OSM Skierniewice \\
\hline $\begin{array}{c}\text { Unsmoked cheeses } \\
\text { Unsmoked cheese-like } \\
\text { products }\end{array}$ & 10 & $\begin{array}{r}\text { SM Mlekovita; Polmlek Sp. z.o.o.; OSM Olecko; SM Mlekpol; } \\
\text { OSM Sierpc; SM Spomlek; SM Zorina; SP Ryki; } \\
\text { SM Włoszczowa; Hochland Polska Sp. z.o.o. }\end{array}$ \\
\hline & 10 & $\begin{array}{c}\text { Polmlek Sp. z.o.o. (two products); Pasłęk Sp. z.o.o. (two } \\
\text { products); TMT Sp. z.o.o.; SM Mlekovita; PHU JAGR Sp. z.o.o.; } \\
\text { PHU Robert Ogorzałek Radom; OSM Włoszczowa; OSM Sierpc }\end{array}$ \\
\hline
\end{tabular}

\subsection{Analytical Methods}

\subsubsection{Fat Extraction}

The lipids were extracted according to the modified Folch's procedure [36]. The studied material was crushed and mixed. Approximately $3 \mathrm{~g}$ of samples $(0.01 \mathrm{~g})$ was homogenized (IKA Ultra-Turrax ${ }^{\circledR} \mathrm{T} 18$ digital) for $1 \mathrm{~min}$ with $30 \mathrm{~mL}$ of methanol. Next, $30 \mathrm{~mL}$ chloroform was added, and the procedure was continued for $2 \mathrm{~min}$. The prepared mixture was filtered to a $250 \mathrm{~mL}$ glass cylinder. The solid residue was mixed in $60 \mathrm{~mL}$ chloroform: methanol (2:1 $v / v)$ and homogenized again for $3 \mathrm{~min}$. The mixture was transferred to the same cylinder. Next, $0.88 \%$ sodium chloride in water 
was added to the total filtrate (in the amount constituting 1/4 volume of filtrate), then shaken and left overnight. The upper layer was removed using a water pump. A water: methanol mixture (1:1 v/v) was added to the lower layer. The washing procedure was repeated. The remaining layer was filtered through anhydrous (VI) sodium sulfate and distilled for complete evaporation of the solvent.

\subsubsection{Preparation of Fatty Acid Methyl Esters}

Fatty acid methyl esters were prepared according to IDF method (ISO 15884:2002) [37]. To do so, $50 \mathrm{mg}$ of extracted fat was placed inside a sealed ampule, then $2.5 \mathrm{~mL}$ hexane was added to dissolve it. The container was shaken vigorously until the fat was completely dissolved. Next, 0.1 $\mathrm{mL} 2 \mathrm{M}$ methanolic $\mathrm{KOH}$ solution was added. The ampule was shaken for $1 \mathrm{~min}$ and then left for 5 more minutes. After that time, $0.25 \mathrm{~g}$ of $\mathrm{NaHSO}_{4} \times \mathrm{H}_{2} \mathrm{O}$ was added and spun for $3 \mathrm{~min}$ in a separator (approximately 1000 spins/min). The top layer of prepared methyl esters was taken for chromatographic analysis.

\subsubsection{Gas Chromatography (GC) Analysis}

The composition of fatty acids was determined applying the method of gas chromatography with the help of Hewlett Packard 6890 GC System (Múnster, Germany) with a flame ionization detector (FID) in 100 m capillary column (produced by Chrompack, Middelburg, the Netherlands) with CP Sil 88 phase. The column diameter was $0.25 \mathrm{~mm}$, and the film was $0.20 \mu \mathrm{m}$ thick. The used separation conditions are presented in Table 2.

Table 2. Parameters of the chromatographic determination.

\begin{tabular}{|c|c|}
\hline Column Temperature & $60^{\circ} \mathrm{C}($ for $1 \mathrm{~min})$ to $180^{\circ} \mathrm{C}, \Delta \mathrm{t}=5^{\circ} \mathrm{C} / \mathrm{min}$ \\
\hline detector temperature & $250{ }^{\circ} \mathrm{C}$ \\
\hline injector temperature & $225^{\circ} \mathrm{C}$ \\
\hline carrier gas & helium \\
\hline gas flow & $1.5 \mathrm{~mL} / \mathrm{min}$ \\
\hline sample injection volume & $0.4 \mu \mathrm{L}$ \\
\hline split ratio & $50: 1$ \\
\hline
\end{tabular}

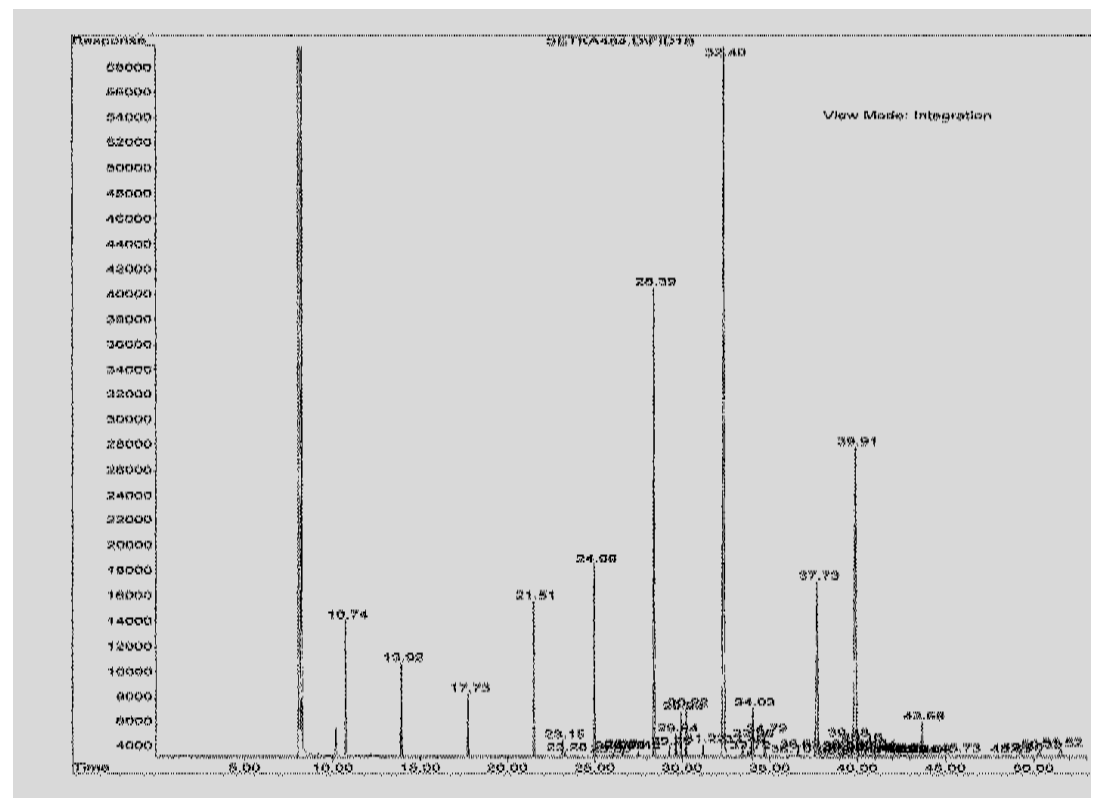

(a)

Figure 1. Cont. 


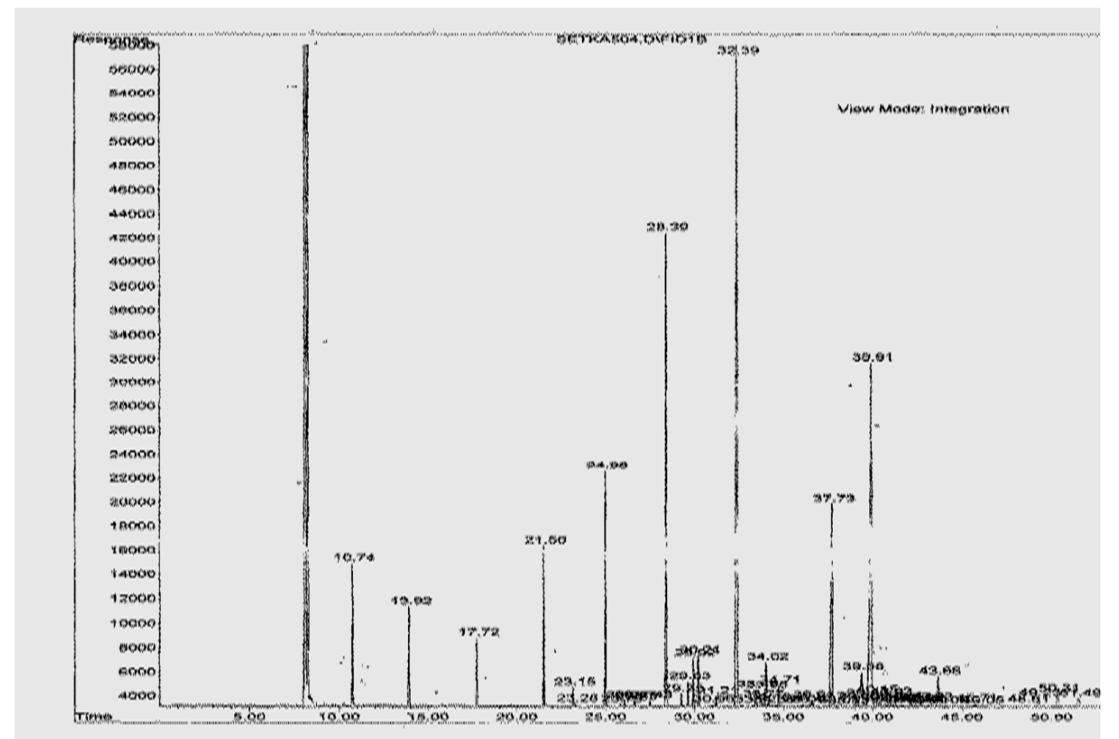

(b)

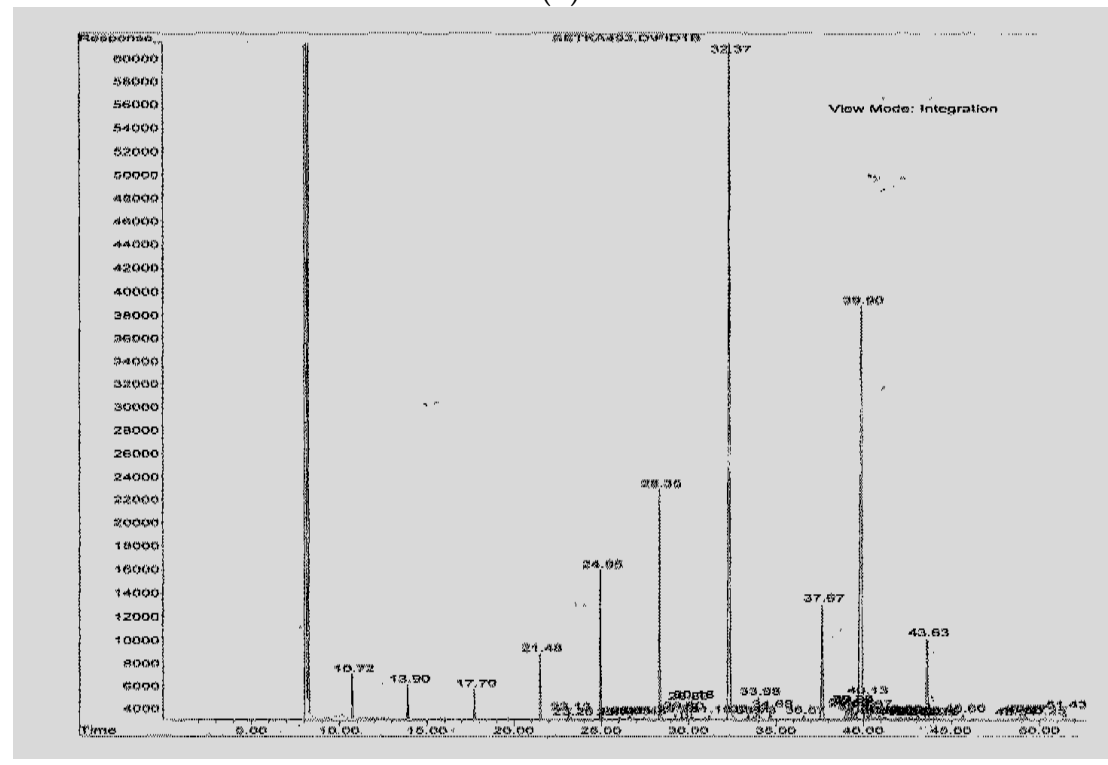

(c)

Figure 1. Chromatogram of separation obtained of reference milk fat (a) of sample smoked cheese (b) and of sample smoked cheese-like products (c).

Identification of fatty acids was carried out based on the comparison of their retention time with the retention time of methyl esters of fatty acids of reference milk fat (BCR Reference Materials) of CRM 164 symbol. Examples of chromatograms are shown in Figure 1. The positional trans isomers of C18:1 were identified using the standards of methyl esters of these isomers (trans6, Supelco and trans 9 and trans11, Sigma-Aldrich, St. Louis, MO, USA), whereas the trans isomers of C18:2 acid (cis,trans and trans,cis) were identified with the use of a mixture of standards of C18:2 isomers (Supelco). The cis9trans11 CLA isomer was identified using a mixture of CLA methyl esters (Sigma-Aldrich). The proportions of the individual acids were calculated by the ratio of their peak area to the total area of all identified acids (\% mass fraction). 
2.3. The Lipid Quality Indices Were Calculated from the Fatty Acids Composition Using the Following Formulae

\subsubsection{Index of Atherogenicity (AI)}

The index of atherogenicity (AI) indicates the relationship between the sum of the main saturated fatty acids and that of the main classes of unsaturated fatty acids. The clotting activity of platelets and their aggregation to a thrombus is closely related to the intake of long-chain SFA. $n-6$ PUFA are antiatherogenic (reduction of serum lipids), whereas $n-3$ PUFA are antithrombogenic (inhibiting the aggregation of platelet, diminishing the levels of cholesterol and phospholipids, thereby preventing the appearance of coronary disease) (Equation (1)) [5,38]:

$$
\mathrm{AI}=(\mathrm{C} 12: 0+(4 \times \mathrm{C} 14: 0)+\mathrm{C} 16: 0) /(\Sigma n-3 \mathrm{PUFA}+\Sigma n-6 \mathrm{PUFA}+\Sigma \mathrm{MUFA})
$$

\subsubsection{Index of Thrombogenicity (TI)}

The index of thrombogenicity (TI) indicates there is a tendency for clots to form in the blood vessels. This is defined as the relationship between the pro-thrombogenetic (saturated) and the anti-thrombogenetic fatty acids (MUFA, PUFA $n-6$ and PUFA $n-3$ ) (Equation $(2)$ ) $[3,18]$.

$$
\begin{gathered}
\mathrm{TI}=(\mathrm{C} 14: 0+\mathrm{C} 16: 0+\mathrm{C} 18: 0) /((0.5 \times \mathrm{C} 18: 1)+(0.5 \times \text { other MUFA })+ \\
(0.5 \times \Sigma n-6 \mathrm{PUFA})+(3 \times \Sigma n-3 \text { PUFA })+\Sigma n-3 \text { PUFA } / \Sigma n-6 \text { PUFA }))
\end{gathered}
$$

\subsubsection{Hypocholesterolemic Fatty Acids (DFA)}

The nutritional quality indices of lipids were determined using the fatty acids, estimating the unsaturated fatty acids (UFA) by summing the polyunsaturated (PUFA) and the monounsaturated (MUFA), and using the desirable saturated fat acids (C18:0) (Equation (3)) [38].

$$
\mathrm{DFA}=\mathrm{UFA}+\mathrm{C} 18: 0
$$

2.3.4. Hypercholesterolemic Fatty Acids (OFA) (Equation (4))

$$
\mathrm{OFA}=\mathrm{C} 12: 0+\mathrm{C} 14: 0+\mathrm{C} 16: 0
$$

2.3.5. Hypocholesterolemic and Hypercholesterolemic Ratio $(\mathrm{H} / \mathrm{H})$

The $\mathrm{H} / \mathrm{H}$ ratio is related to the functional activity of fatty acids in the metabolism of lipoproteins regarding plasma cholesterol transport and the risk of cardiovascular disease. The ratio of hypocholesterolemic and hypercholesterolemic fatty acids $(\mathrm{H} / \mathrm{H})$ was calculated according to Ivanova and Hadzhinikolova (Equation (5)) [39].

$$
\mathrm{H} / \mathrm{H}=(\mathrm{C} 18: 1 n-9+\mathrm{C} 18: 2 n-6+\mathrm{C} 18: 3 n-3) /(\mathrm{C} 12: 0+\mathrm{C} 14: 0+\mathrm{C} 16: 0)
$$

\subsection{Statistical Analysis}

The statistical analyses were calculated using STATISTICA ver. 13.1 software (Statsoft, Kraków, Poland) [40]. The one-way analysis of variance ANOVA (Duncan's test) was used to test significant differences between the content of fatty acids. The significance level of $p<0.05$ was used. 


\section{Results}

\subsection{Fatty Acid Composition and Lipid Quality Indices in the Cheeses and the Cheese-Like Products}

The fatty acid composition and the total content of fatty acid groups in the smoked and the unsmoked cheeses and cheese-like products are presented in Table 3. The obtained results indicate that the smoked and the unsmoked cheeses and cheese-like products were characterized by a diversified content of fatty acids. The unsmoked cheeses had a significantly higher total content of saturated fatty acids (SFA) $(63.65 \pm 1.92 \%)(p<0.05)$ compared to the other analyzed products (Table 3$)$. The smoked cheeses had significantly lower total content of SFA but also had a significantly higher $(p<0.05)$ content of short-chain fatty acids (SCFA) $(10.07 \pm 0.37 \%)$. In smoked and unsmoked cheese-like products, total content of both SFA and SCFA were significantly lower $(p<0.05)$. In all cheeses and cheese-like products, in the group of SFA, the palmitic acid (C16:0), the myristic acid (C14:0), and the stearic acid (C18:0) were found in the highest contents (Table 3). The monounsaturated fatty acids (MUFA) and the polyunsaturated fatty acids (PUFA) contents were the highest in unsmoked cheese-like products $(39.29 \pm 1.49 \%$ and $9.13 \pm 0.33 \%$, respectively). In other products, the content of these acids was significantly lower $(p<0.05)$. Smoked and unsmoked cheeses were characterized by similar contents of MUFA and PUFA (over $24 \%$ and over $2.5 \%$, respectively) (Table 3 ). The smoked and the unsmoked cheeses had higher contents of branched-chain fatty acids (BCFA) compared to smoked and unsmoked cheese-like products (Table 3). In unsmoked cheese-like products, only C15:0 iso and C15: 0 aiso were present in amounts of $0.03 \%$ and $0.04 \%$, respectively.

In the cheeses and the cheese-like products, the values of lipid quality indices were varied. The content of desirable hypocholesterolemic fatty acids (DFAs) had the highest significance $(p<0.05)$ in the unsmoked cheese-like products $(53.15 \pm 1.87)$ (Table 4$)$. In smoked and unsmoked cheeses, DFA had similar values (36.72 \pm 0.89 and $36.49 \pm 2.17$, respectively) (Table 4). Significantly lower values of OFA were found in the smoked and the unsmoked cheese-like products than in the smoked and the unsmoked cheeses. In the presented study (Table 4), the AI value in the unsmoked cheese-like products was the lowest $(0.98 \pm 0.10)$. Significantly higher $(p<0.05)$ AI values were found in the other analyzed products. The unsmoked cheese-like products also had the lowest TI value $(2.00 \pm 0.31)$. Significantly higher $(p<0.05)$ values of TI were found in the smoked cheese-like products and the smoked and the unsmoked cheeses. In the current study, the lowest values of the hypocholesterolemic/hypercholesterolemic fatty acids ratio were found in the smoked and the unsmoked cheeses (0.41) (Table 4). Significantly higher $(p<0.05)$ values of the $\mathrm{H} / \mathrm{H}$ ratio were found in smoked and unsmoked cheese-like products $(0.90 \pm 0.04$ and $1.03 \pm 0.06$, respectively). 
Table 3. The fatty acids composition in analyzed products ( $\%$ of total fatty acids) (Mean \pm SD, range)

\begin{tabular}{|c|c|c|c|c|c|c|c|c|}
\hline \multirow{3}{*}{$\begin{array}{c}\text { Fatty Acids } \\
\mathbf{n}\end{array}$} & \multicolumn{2}{|c|}{ Smoked Cheeses } & \multicolumn{2}{|c|}{ Smoked Cheese-Like Products } & \multicolumn{2}{|c|}{ Unsmoked Cheeses } & \multicolumn{2}{|c|}{ Unsmoked Cheese-Like Products } \\
\hline & \multicolumn{2}{|c|}{10} & \multicolumn{2}{|c|}{4} & \multicolumn{2}{|c|}{10} & \multicolumn{2}{|c|}{10} \\
\hline & Mean \pm SD & (Min-Max) & Mean \pm SD & (Min-Max) & Mean \pm SD & (Min-Max) & Mean \pm SD & (Min-Max) \\
\hline C4:0 & $3.07 \pm 0.13^{\mathrm{a}}$ & $(2.88-3.26)$ & $0.90 \pm 0.57^{c}$ & $(0.37-1.48)$ & $2.20 \pm 0.90^{b}$ & $(0.84-3.23)$ & $0.14 \pm 0.11^{\mathrm{d}}$ & $(0.03-0.34)$ \\
\hline C6:0 & $2.29 \pm 0.21^{\mathrm{a}}$ & $(2.07-2.83)$ & $0.64 \pm 0.39^{c}$ & $(0.28-1.03)$ & $1.93 \pm 0.30^{b}$ & $(1.45-2.24)$ & $0.10 \pm 0.07^{\mathrm{d}}$ & $(0.03-0.22)$ \\
\hline C8:0 & $1.43 \pm 0.05^{\mathrm{a}}$ & $(1.34-1.50)$ & $0.43 \pm 0.24^{b}$ & $(0.21-0.66)$ & $1.36 \pm 0.08^{a}$ & $(1.25-1.50)$ & $0.11 \pm 0.07^{c}$ & $(0.06-0.23)$ \\
\hline $\mathrm{C} 10: 0$ & $3.27 \pm 0.10^{\mathrm{a}}$ & $(3.12-3.46$ & $0.94 \pm 0.52^{b}$ & $(0.47-1.40)$ & $3.34 \pm 0.26^{\mathrm{a}}$ & $(3.09-3.99)$ & $0.15 \pm 0.10^{c}$ & $(0.09-0.39)$ \\
\hline$\Sigma$ SCFA $^{1}$ & $10.07 \pm 0.37^{a}$ & $(9.41-10.51)$ & $2.92 \pm 1.71^{\mathrm{c}}$ & $(1.33-4.57)$ & $8.82 \pm 1.19^{b}$ & $(7.07-10.06)$ & $0.31 \pm 0.36^{\mathrm{d}}$ & $(0.00-1.18)$ \\
\hline C11:0 & $0.06 \pm 0.00^{\mathrm{a}}$ & $(0.06-0.07)$ & ND & & $0.07 \pm 0.01^{\mathrm{a}}$ & $(0.05-0.09)$ & ND & \\
\hline $\mathrm{C} 13: 0$ & $0.22 \pm 0.01^{\mathrm{a}}$ & $(0.21-0.24)$ & $0.06 \pm 0.03^{c}$ & $(0.03-0.09)$ & $0.13 \pm 0.02^{b}$ & $(0.10-0.15)$ & ND & \\
\hline $\mathrm{C} 15: 0$ & $1.29 \pm 0.06^{\mathrm{a}}$ & (1.19-1.37) & $0.40 \pm 0.21^{b}$ & $(0.21-0.58)$ & $1.26 \pm 0.07^{a}$ & (1.19-1.39) & $0.06 \pm 0.05^{c}$ & $(0.01-0.16)$ \\
\hline $\mathrm{C} 17: 0$ & $0.57 \pm 0.02^{b}$ & $(0.55-0.59)$ & $0.22 \pm 0.08^{c}$ & $(0.14-0.32)$ & $1.14 \pm 0.47^{\mathrm{a}}$ & $(0.70-1.72)$ & $0.11 \pm 0.02^{c}$ & $(0.10-0.15)$ \\
\hline C19:0 & $0.08 \pm 0.01^{b}$ & $(0.07-0.09)$ & $0.03 \pm 0.04^{c}$ & $(0.00-0.08)$ & $0.15 \pm 0.02^{\mathrm{a}}$ & $(0.12-0.18)$ & ND & \\
\hline$\Sigma$ OCFA $^{2}$ & $2.23 \pm 0.09^{b}$ & $(2.07-2.32)$ & $0.72 \pm 0.36^{c}$ & (0.39-1.08) & $2.74 \pm 0.49^{a}$ & $(2.22-3.46)$ & $0.19 \pm 0.06^{d}$ & $(0.10-0.31)$ \\
\hline $\mathrm{C} 13: 0$ iso & $0.12 \pm 0.01^{\mathrm{a}}$ & $(0.11-0.12)$ & $0.02 \pm 0.03^{b}$ & $(0.00-0.05)$ & $0.11 \pm 0.01^{\mathrm{a}}$ & $(0.09-0.12)$ & ND & \\
\hline $\mathrm{C} 14: 0$ iso & $0.15 \pm 0.02^{\mathrm{a}}$ & $(0.13-0.18)$ & $0.04 \pm 0.02^{b}$ & $(0.02-0.06)$ & $0.13 \pm 0.01^{a}$ & $(0.12-0.15)$ & ND & \\
\hline $\mathrm{C} 15: 0$ iso & $0.28 \pm 0.02^{\mathrm{a}}$ & $(0.26-0.33)$ & $0.09 \pm 0.04^{b}$ & $(0.05-0.13)$ & $0.26 \pm 0.02^{\mathrm{a}}$ & $(0.23-0.29)$ & $0.03 \pm 0.01^{c}$ & $(0.02-0.04)$ \\
\hline $\mathrm{C} 16: 0$ iso & $0.30 \pm 0.01^{\mathrm{a}}$ & $(0.28-0.32)$ & $0.09 \pm 0.06^{b}$ & $(0.04-0.14)$ & $0.32 \pm 0.02^{\mathrm{a}}$ & $(0.29-0.34)$ & ND & \\
\hline $\mathrm{C} 17: 0$ iso & $0.17 \pm 0.01^{b}$ & $(0.15-0.18)$ & $0.07 \pm 0.05^{c}$ & $(0.00-0.11)$ & $0.35 \pm 0.02^{\mathrm{a}}$ & $(0.32-0.39)$ & ND & \\
\hline C17:0 aiso & $0.56 \pm 0.02^{\mathrm{a}}$ & $(0.53-0.59)$ & $0.13 \pm 0.15^{c}$ & $(0.00-0.27)$ & $0.24 \pm 0.09^{b}$ & $(0.18-0.42)$ & ND & \\
\hline$\Sigma$ BCFA $^{3}$ & $2.09 \pm 0.08^{a}$ & $(1.99-2.24)$ & $0.59 \pm 0.43^{c}$ & (0.18-1.01) & $1.94 \pm 0.12^{b}$ & $(1.79-2.14)$ & $0.07 \pm 0.04^{d}$ & $(0.04-0.11)$ \\
\hline $\mathrm{C} 12: 0$ & $3.80 \pm 0.10^{\mathrm{a}}$ & (3.63-4.01) & $1.22 \pm 0.53^{b}$ & (0.74-1.71) & $3.99 \pm 0.39^{a}$ & $(3.55-4.94)$ & $1.03 \pm 0.57^{b}$ & $(0.25-1.74)$ \\
\hline C14:0 & $12.16 \pm 0.23^{a}$ & $(11.73-12.46)$ & $4.10 \pm 1.66^{b}$ & $(2.65-5.68)$ & $12.65 \pm 1.03^{a}$ & (11.81-15.13) & $1.59 \pm 0.49^{c}$ & $(1.29-1.42)$ \\
\hline $\mathrm{C} 16: 0$ & $32.19 \pm 0.97^{c}$ & $(29.98-33.23)$ & $40.48 \pm 3.69^{b}$ & $(36.60-43.77)$ & $33.07 \pm 1.02^{c}$ & (32.09-34.85) & $43.67 \pm 2.08^{a}$ & $(40.92-46.88)$ \\
\hline $\mathrm{C} 18: 0$ & $9.01 \pm 0.22^{a}$ & $(8.72-9.34)$ & $5.99 \pm 1.22^{b}$ & $(4.91-7.14)$ & $9.12 \pm 0.83^{a}$ & (7.48-10.39) & $4.73 \pm 0.92^{c}$ & $(4.15-7.24)$ \\
\hline C20:0 & $0.15 \pm 0.01^{\mathrm{c}}$ & $(0.14-0.18)$ & $0.28 \pm 0.03^{b}$ & $(0.25-0.30)$ & $0.14 \pm 0.02^{c}$ & $(0.09-0.17)$ & $0.35 \pm 0.05^{\mathrm{a}}$ & $(0.31-0.48)$ \\
\hline
\end{tabular}


Table 3. Cont.

\begin{tabular}{|c|c|c|c|c|c|c|c|c|}
\hline \multirow{3}{*}{$\begin{array}{c}\text { Fatty Acids } \\
\mathbf{n}\end{array}$} & \multicolumn{2}{|c|}{ Smoked Cheeses } & \multicolumn{2}{|c|}{ Smoked Cheese-Like Products } & \multicolumn{2}{|c|}{ Unsmoked Cheeses } & \multicolumn{2}{|c|}{ Unsmoked Cheese-Like Products } \\
\hline & \multicolumn{2}{|c|}{10} & \multicolumn{2}{|c|}{4} & \multicolumn{2}{|c|}{10} & \multicolumn{2}{|c|}{10} \\
\hline & Mean \pm SD & (Min-Max) & Mean \pm SD & (Min-Max) & Mean \pm SD & (Min-Max) & Mean \pm SD & (Min-Max) \\
\hline$\Sigma$ MCFA+LCFA ${ }^{4}$ & $57.31 \pm 1.25^{b}$ & $(54.20-58.76)$ & $52.07 \pm 0.72^{c}$ & $(51.03-52.64)$ & $58.98 \pm 1.84^{a}$ & $(57.12-62.47)$ & $50.68 \pm 1.47^{\mathrm{d}}$ & $(48.95-52.28)$ \\
\hline$\Sigma$ SFA $^{5}$ & $61.63 \pm 1.24{ }^{b}$ & $(58.40-62.90)$ & $53.38 \pm 0.89^{c}$ & $(52.88-54.62)$ & $63.65 \pm 1.92^{\mathrm{a}}$ & $(61.55-67.89)$ & $50.59 \pm 1.51^{\mathrm{d}}$ & $(48.57-52.44)$ \\
\hline $\mathrm{C} 10: 1$ & $0.35 \pm 0.01^{\mathrm{a}}$ & $(0.33-0.38$ & $0.09 \pm 0.06^{b}$ & $(0.04-0.14)$ & $0.34 \pm 0.02^{a}$ & $(0.31-0.39)$ & ND & \\
\hline $\mathrm{C} 12: 1$ & $0.04 \pm 0.01^{b}$ & $(0.03-0.04)$ & ND & & $0.09 \pm 0.01^{\mathrm{a}}$ & $(0.08-0.11)$ & ND & \\
\hline $\mathrm{C} 14: 1$ & $1.18 \pm 0.05^{\mathrm{a}}$ & $(1.11-1.28)$ & $0.29 \pm 0.16^{b}$ & $(0.15-0.43)$ & $1.14 \pm 0.08^{a}$ & $(1.03-1.33)$ & $0.06 \pm 0.04^{c}$ & $(0.03-0.09)$ \\
\hline $\mathrm{C} 16: 1$ & $1.67 \pm 0.05^{\mathrm{a}}$ & $(1.62-1.80)$ & $0.55 \pm 0.23^{c}$ & $(0.35-0.75)$ & $1.12 \pm 0.73^{b}$ & $(0.32-2.16)$ & $0.20 \pm 0.04^{c}$ & $(0.16-0.27)$ \\
\hline$t 6-t 9$ C $18: 1$ & $0.38 \pm 0.02^{b}$ & $(0.36-0.41)$ & $0.15 \pm 0.06^{c}$ & $(0.10-0.20)$ & $0.41 \pm 0.03^{b}$ & $(0.34-0.45)$ & $1.15 \pm 1.00^{\mathrm{a}}$ & $(0.05-2.92)$ \\
\hline$t 10+t 11 C 18: 1$ & $1.25 \pm 0.17^{\mathrm{a}}$ & $(1.02-1.64)$ & $0.48 \pm 0.36^{b}$ & $(0.17-0.81)$ & $1.14 \pm 0.16^{\mathrm{a}}$ & (0.86-1.38) & $0.18 \pm 0.07^{c}$ & $(0.13-0.30)$ \\
\hline$t 12$ C18:1 & $0.23 \pm 0.02^{a}$ & $(0.20-0.26)$ & $0.07 \pm 0.06^{b}$ & $(0.02-0.12)$ & $0.27 \pm 0.03^{a}$ & $(0.21-0.32)$ & ND & \\
\hline c9 C18:1 & $18.23 \pm 0.42^{c}$ & $(17.33-18.67)$ & $32.57 \pm 2.52^{b}$ & $(30.25-34.79)$ & $18.61 \pm 0.81^{c}$ & $(17.30-20.10)$ & $36.43 \pm 1.00^{\mathrm{a}}$ & (35.04-38.71) \\
\hline c11 C18:1 & $0.64 \pm 0.03^{c}$ & $(0.59-0.69)$ & $0.98 \pm 0.10^{b}$ & $(0.91-1.12)$ & $0.61 \pm 0.05^{c}$ & $(0.53-0.68)$ & $1.15 \pm 0.06^{\mathrm{a}}$ & $(1.07-1.24)$ \\
\hline c12 C18:1 & $0.26 \pm 0.02^{\mathrm{a}}$ & $(0.22-0.28)$ & $0.12 \pm 0.12^{b}$ & $(0.02-0.26)$ & $0.27 \pm 0.03^{a}$ & $(0.21-0.33)$ & $0.21 \pm 0.07^{\mathrm{a}}$ & $(0.14-0.28)$ \\
\hline c13 C18:1 & $0.09 \pm 0.01^{\mathrm{a}}$ & $(0.08-0.10)$ & $0.05 \pm 0.03^{b}$ & $(0.03-0.09)$ & $0.09 \pm 0.01^{\mathrm{a}}$ & $(0.07-0.10)$ & $0.05 \pm 0.02^{b}$ & $(0.03-0.06)$ \\
\hline$t 16$ C18:1 & $0.28 \pm 0.02^{\mathrm{a}}$ & $(0.24-0.31)$ & $0.08 \pm 0.09^{b}$ & $(0.00-0.18)$ & $0.27 \pm 0.03^{a}$ & $(0.22-0.32)$ & $0.04 \pm 0.01^{b}$ & $(0.03-0.04)$ \\
\hline$\Sigma$ MUFA $^{6}$ & $24.78 \pm 0.59^{c}$ & $(24.26-25.78$ & $35.64 \pm 1.32^{b}$ & $(34.18-36.79)$ & $24.72 \pm 1.29^{c}$ & $(22.30-26.75)$ & $39.29 \pm 1.49^{a}$ & $(37.39-41.20)$ \\
\hline$c 9 t 13$ C18:2 & $0.19 \pm 0.02^{b}$ & $(0.15-0.24)$ & $0.05 \pm 0.03^{c}$ & $(0.02-0.08)$ & $0.16 \pm 0.01^{b}$ & $(0.15-0.18)$ & $0.34 \pm 0.06^{\mathrm{a}}$ & $(0.29-0.45)$ \\
\hline$c 9 t 12$ C18:2 & $0.27 \pm 0.02^{\mathrm{a}}$ & $(0.24-0.31)$ & $0.22 \pm 0.05^{b}$ & $(0.16-0.26)$ & ND & & ND & \\
\hline$t 9 c 12$ C $18: 2$ & ND & & ND & & $0.15 \pm 0.02$ & $(0.12-0.17)$ & ND & \\
\hline$t 11 c 15$ C18:2 & $0.12 \pm 0.06^{\mathrm{a}}$ & $(0.06-0.15)$ & $0.16 \pm 0.06^{\mathrm{a}}$ & $(0.09-0.21)$ & $0.08 \pm 0.03^{b}$ & $(0.05-0.11)$ & ND & \\
\hline$c 9 c 12$ C18:2 n-6 & $1.31 \pm 0.12^{c}$ & (1.15-1.54) & $7.26 \pm 1.08^{b}$ & $(6.11-8.20)$ & $1.53 \pm 0.17^{c}$ & (1.30-1.86) & $8.80 \pm 0.43^{a}$ & $(8.08-9.36)$ \\
\hline$c 9 c 12 c 15 \mathrm{C} 18: 3 n-3$ & $0.38 \pm 0.06^{\mathrm{a}}$ & $(0.29-0.46)$ & $0.23 \pm 0.08^{c}$ & $(0.16-0.30)$ & $0.31 \pm 0.06^{b}$ & $(0.23-0.42)$ & $0.15 \pm 0.02^{\mathrm{d}}$ & $(0.12-0.20)$ \\
\hline c9t11 C18:2 (CLA) & $0.49 \pm 0.10^{\mathrm{a}}$ & $(0.38-0.72)$ & $0.18 \pm 0.14^{b}$ & $(0.07-0.31)$ & $0.41 \pm 0.06^{\mathrm{a}}$ & $(0.28-0.48)$ & $0.06 \pm 0.05^{\mathrm{c}}$ & $(0.02-0.09)$ \\
\hline$\Sigma$ PUFA $^{7}$ & $2.75 \pm 0.20^{c}$ & $(2.45-3.09)$ & $8.09 \pm 0.96^{b}$ & $(7.02-8.91)$ & $2.64 \pm 0.22^{c}$ & $(2.15-2.91$ & $9.13 \pm 0.33^{a}$ & $(8.50-9.50)$ \\
\hline$\Sigma$ UFA $^{8}$ & $27.71 \pm 0.75^{c}$ & $(26.72-28.97)$ & $43.72 \pm 2.28^{b}$ & $(41.20-45.70)$ & $27.37 \pm 1.40^{c}$ & $(24.45-29.41)$ & $48.42 \pm 1.46^{\mathrm{a}}$ & $(46.38-50.57)$ \\
\hline
\end{tabular}


Table 4. Lipid quality indices in products (Mean \pm SD).

\begin{tabular}{ccccc}
\hline Fatty Acids & Smoked Cheeses & $\begin{array}{c}\text { Smoked Cheese-Like } \\
\text { Products }\end{array}$ & $\begin{array}{c}\text { Unsmoked } \\
\text { Cheeses }\end{array}$ & $\begin{array}{c}\text { Unsmoked } \\
\text { Cheese-Like Products }\end{array}$ \\
\hline $\mathbf{n}$ & $\begin{array}{c}\mathbf{1 0} \\
\text { Mean } \pm \text { SD }\end{array}$ & $\begin{array}{c}\mathbf{4} \\
\text { Mean } \pm \mathbf{S D}\end{array}$ & $\begin{array}{c}\mathbf{1 0} \\
\text { Mean } \pm \text { SD }\end{array}$ & $\begin{array}{c}\mathbf{1 0} \\
\text { Mean } \pm \text { SD }\end{array}$ \\
\hline DFA $^{\mathbf{1}}$ & $36.72 \pm 0.89^{\mathrm{c}}$ & $49.71 \pm 1.15^{\mathrm{b}}$ & $36.49 \pm 2.17^{\mathrm{c}}$ & $53.15 \pm 1.87^{\mathrm{a}}$ \\
$\mathbf{O F A}^{\mathbf{2}}$ & $52.68 \pm 1.23^{\mathrm{a}}$ & $47.39 \pm 1.01^{\mathrm{b}}$ & $54.53 \pm 2.51^{\mathrm{a}}$ & $45.86 \pm 1.87^{\mathrm{b}}$ \\
$\mathbf{A I}^{\mathbf{3}}$ & $3.18 \pm 0.09^{\mathrm{a}}$ & $1.35 \pm 0.16^{\mathrm{b}}$ & $3.31 \pm 0.36^{\mathrm{a}}$ & $0.98 \pm 0.10^{\mathrm{c}}$ \\
$\mathbf{T I}^{\mathbf{4}}$ & $3.66 \pm 0.14^{\mathrm{b}}$ & $2.28 \pm 0.08^{\mathrm{c}}$ & $3.86 \pm 0.27^{\mathrm{a}}$ & $2.00 \pm 0.13^{\mathrm{d}}$ \\
$\mathbf{H}^{\mathbf{5}} \mathbf{H}^{\mathbf{5}}$ & $0.41 \pm 0.01^{\mathrm{c}}$ & $0.87 \pm 0.05^{\mathrm{b}}$ & $0.41 \pm 0.03^{\mathrm{c}}$ & $1.00 \pm 0.05^{\mathrm{a}}$ \\
\hline
\end{tabular}

$\mathrm{n}$-number of samples, Mean-mean value; SD—standard deviation; ${ }^{\mathrm{a}, \mathrm{b}, \mathrm{c}, \mathrm{d}}$ - values denoted in rows by different letters indicate statistically significant differences $(p<0.05) ;{ }^{1}$ DFA-hypocholesterolemic fatty acids $(\Sigma \mathrm{UFA}+$ C18:0); ${ }^{2}$ OFA - hypercholesterolemic fatty acids ( $\mathrm{SSFA}$ - C18:0), ${ }^{3} \mathrm{AI}$ (Index of Atherogenicity); ${ }^{4}$ TI (Index of Thrombogenicity), ${ }^{5}$ H/H (hypocholesterolemic/hypercholesterolemic ratio).

\subsection{Trans Fatty Acids (TFA) in Cheeses and Cheese-Like Products}

Figure 2 shows the content of trans isomers of C18:1 acid and trans isomers of C18:2 acid and cis9trans11 C18:2 (CLA) in the cheeses and the cheese-like products. In smoked and unsmoked cheeses, the total content of trans C18:1 was at a similar level. A significantly lower $(p<0.05)$ content of these isomers was found in unsmoked and smoked cheese-like products ( $1.27 \%$ and $0.77 \%$, respectively).

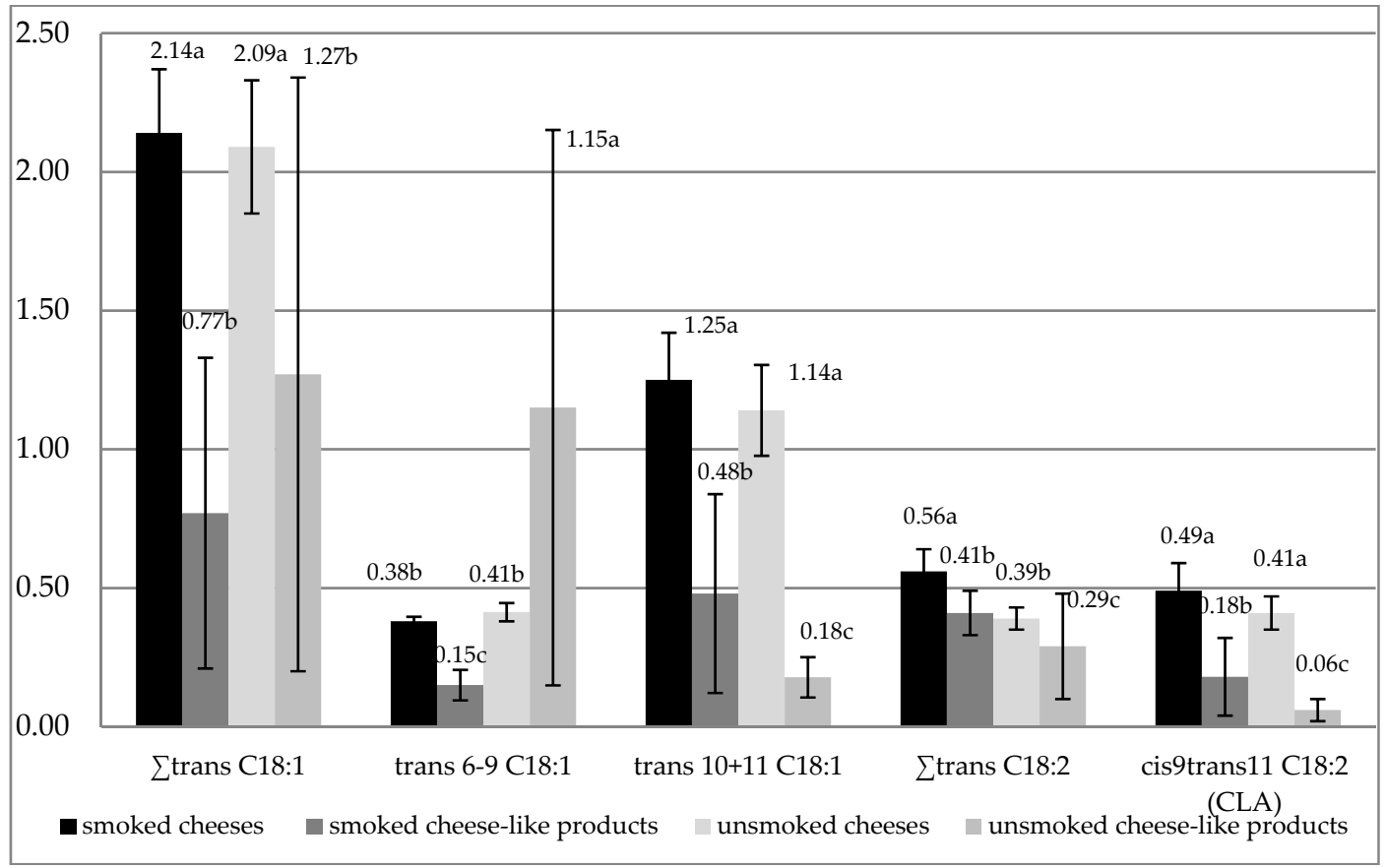

Figure 2. The content of $\mathrm{C} 18: 1$ and $\mathrm{C} 18: 2$ trans isomers and cis9trans $11 \mathrm{C} 18: 2$ (CLA) in products (\% of total fatty acids) (mean $\pm \mathrm{SD}$ ); $\sum$ trans $\mathrm{C} 18: 1$-all trans isomers of C18:1 $(t 6-t 9 \mathrm{C} 18: 1, t 10+t 11 \mathrm{C} 18: 1, t 12$ C18:1, t16 C18:1), Etrans C18:2-all trans isomers of C18:2 (c9t13 C18:2, c9t12 C18:2, t9c12 C18:2, t11. C18:2) without $c 9 t 11$ C18:2), a,b,c-values denoted by different letters indicate statistically significant differences in the content of trans C18:1, C18:2 isomers and cis9trans11 C18:2 CLA $(p<0.05)$.

It was found that, in all samples of cheeses in the group of trans $C 18: 1$, the highest amount of trans 10 + trans 11 isomers were found (Table 3). The contents of these isomers in the smoked cheeses ranged from $1.02 \%$ to $1.64 \%$, and in the unsmoked cheeses, they ranged from $0.86 \%$ to $1.38 \%$. Other marked trans isomers of $\mathrm{C} 18: 1$ in the cheeses were in smaller amounts. In the cheese-like products, the contents of trans $10+$ trans 11 isomers were lower (from $0.17 \%$ to $0.81 \%$ in the smoked cheese-like products and 
from $0.13 \%$ to $0.30 \%$ in the unsmoked cheese-like products). The conducted research showed that, in the cheese-like products, the contents of marked trans isomers were very diverse (Table 3). In the unsmoked cheese-like products, the contents of trans6-trans 9 isomers ranged from $0.05 \%$ to $2.92 \%$ and in the smoked cheese-like products from $0.10 \%$ to $0.20 \%$.

The smoked cheeses were characterized by the highest content of trans C18:2 isomers $(0.56 \%$ of total fatty acids) (Figure 2). Significantly lower $(p<0.05)$ contents of these isomers were found in unsmoked cheeses and smoked and unsmoked cheese-like products.

The conducted analyses demonstrated differences in cis9trans11 C18:2 (CLA) content in the cheeses and the cheese-like products (Table 3, Figure 2). No significant differences were found in the content of CLA in smoked and unsmoked cheeses. In the smoked cheeses, the mean content of CLA was the highest $(0.49 \%$ of total fatty acids), while in the unsmoked cheeses, it was $0.41 \%$. Significantly lower $(p<0.05)$ mean contents of CLA were found in the smoked and the unsmoked cheese-like products $(0.18 \%$ and $0.06 \%$, respectively).

\section{Discussion}

The profiles of fatty acids in commercial cheeses were determined by various authors such as Rutkowska et al. [41], Zlatonos et al. [42], Grega et al. [43], Talupr et al. [44], Domagała et al. [45], and Paszczyk et al. [46]. In the literature, there is a lack of data on the fatty acid profile of smoked dairy products. According to the literature data, the fatty acid composition in milk fat depends on many different factors such as cow's diet, season, breed, lactation stage, age, and geographical location [9,47-50]. The fatty acid profile of dairy products (cheese, butter, fermented milk products) is a result of the raw milk composition and the conditions used in the production process as well as the activity of added starter cultures and ripening time [51-54]. According to the research by Rutkowska et al. [41] and Zeppa et al. [55], the cheeses from the summer period had a higher UFA content and a lower SFA content compared to cheeses from the winter period. The research showed that the contents of SFA, MUFA, and PUFA in smoked and unsmoked cheeses were at similar levels. In smoked and unsmoked cheese-like products, the fatty acid profiles were varied (Table 3). Partial replacement of milk fat with vegetable fats in cheese-like products caused changes in the fatty acid profile of these products compared to the cheeses. Smoked and unsmoked cheese-like products had lower SFA content and higher MUFA and PUFA contents than cheeses (Table 3). Cheeses with rape oil added analyzed by Ritvanen et al. [56] contained only $7.51 \%$ of SFA and were characterized by the higher contents of MUFA and PUFA. In the presented study (Table 3) and the study by Paszczyk et al. [46], the mean contents of MUFA and PUFA in cheese-like products were lower compared to products analyzed by Ritvanen et al. [56].

Milk fat is the main source of SCFA in the diet. Short-chain fatty acids are important from a nutritional point of view, since they possess specific properties associated with important physiological functions. Butyric acid (C4:0) has a beneficial effect on the intestinal flora, has anti-inflammatory activity, and is a factor preventing progression of colorectal cancer and mammary cancer $[57,58]$. The content of SCFA in the studied products was varied (Table 3). The smoked cheeses were characterized by the highest content of SCFA. Significantly lower $(p<0.05)$ contents of these acids were found in other products. Commercial cheeses analyzed by Paszczyk et al. [46] were characterized by higher content of SCFA and unsmoked cheese-like products by lower content of SFA compared to samples of cheeses and cheese-like products analyzed in this study.

Adequate intakes of both $n-6$ and $n-3$ fatty acids are essential for good health and low risk of cardiovascular disease and type 2 diabetes [59-62]. Excessive amounts of $n-6$ PUFA and a very high $n-6 / n-3$ ratio promote the pathogenesis of many diseases, including cardiovascular disease, cancer, and inflammatory and autoimmune diseases, whereas increased levels of $n-3$ PUFA (a lower $n-6 / n-3$ ratio) exert suppressive effects. Studies indicate that the optimal ratio may vary with the disease under consideration [63,64]. In milk fat, the main PUFA are linoleic acid (cis9cis12 C18:2, n-6) and $\alpha$-linolenic acid (cis 9 cis $12 \operatorname{cis} 15 \mathrm{C} 18: 3, n-3$ ). The contents of these acids in milk fat are about $1.6 \%$ and $0.7 \%$ of total 
fatty acid composition, respectively [2]. In smoked and unsmoked cheeses, content of linoleic acid was at a similar level. The content of linoleic acid was lower than in milk $(0.38 \%$ and $0.31 \%$, respectively) (Table 3). A significantly higher $(p<0.05)$ content of C18:2 acid was found in smoked and unsmoked cheese-like products $(7.26 \pm 1.08 \%$ and $8.80 \pm 0.43 \%$, respectively) (Table 3$)$. The content of C18:3 acid in smoked and unsmoked cheese-like products was lower than in cheeses. The higher contents of C18:2 and C18:3 acid in cheeses with rape oil were found by Ritvanen et al. [56]. The AI and the TI indices are of interest to human nutrition, and they are related to the risk of development of cardiovascular diseases [5]. The higher the values of these coefficients are, the higher risk of developing cardiovascular diseases is, because AI indicates the risk of diseases such as atherosclerosis (deposition of fat in the walls of the arteries), and TI determines the possibility of blood clots [39]. In the present study, both AI and TI indices were lower in the smoked and the unsmoked cheese-like products than in cheeses (Table 4).

The most prominent trans fatty acids (TFA) in the human diet are monounsaturated fatty acids with 18 carbon atoms. The main TFA in milk fat is trans 11 C18:1 (vaccenic acid, VA), and its contents can be influenced by the animal feeding system $[65,66]$. Under conventional ruminant diets, milk VA percentage is around $40-50 \%$ of total C18:1 TFA, whereas trans 9 and trans 10 C18:1 are only present in small amounts (5\% and $10 \%$ on average, respectively) $[67,68]$. Thus, the consumption of dairy fat would represent a very low intake of trans 9 and trans 10 C18:1 isomers, while it is a good source of VA, often described as the "natural TFA". In contrast, during the industrial hydrogenation of vegetable oils or fats, a wide range of monounsaturated TFA are generated, and the major isomers are trans 9 C18:1 and trans $10 \mathrm{C} 18: 1$. There is scientific evidence that some fatty acids with a trans configuration have an adverse effect on blood lipids and thereby increase the risk of coronary heart disease [69,70]. In analyzed smoked and unsmoked cheeses, trans C18:1 isomers were significantly higher than in smoked and unsmoked cheese-like products (Figure 2). The total content of trans C18:1 isomers in the commercial cheeses studied by Żegarska et al. [71] was very varied. The content of this group of fatty acids analyzed by Paszczyk et al. [46] in commercial unsmoked cheeses was higher compared to the studied unsmoked cheeses, and in cheese-like products, this content was at a similar level.

The principal natural sources of CLA in the human diet are dairy products from ruminant animals (such as milk, yogurt, and cheese) and meat. The content of CLA in milk ranged from 2 to 23.6 mg CLA/g lipid [72] with cis 9 , trans 11 C18:2 as the major isomer (75\% to $90 \%$ of total CLA) [73,74]. The smoked and the unsmoked cheeses were characterized by a higher content of cis 9 trans $11 \mathrm{C} 18: 2$ (CLA) compared to cheese-like products (Figure 2, Table 3). In smoked and unsmoked cheeses, the content of CLA was at a similar level (Table 3). The content of linoleic acid c9t11 C18:2 (CLA) (0.49\% and $0.41 \%$, respectively) was lower than in milk as studied by Månsson [2]. The differences in CLA content in cheese samples may be explained by differences in origin of cheeses, conditions used during the production process (temperature, type of starter cultures, ripening process), and initial CLA content of raw milk used for making cheeses. Lower content of CLA in cheese-like products may be caused by a small proportion of milk fat in the composition of these products. According to Grega et al. [43] and Żegarska et al. [71], the CLA content in commercial cheeses was varied. The authors found a higher content of this acid in cheeses from summer. In commercial cheeses and cheese-like products analyzed by Paszczyk et al. [43], mean contents of CLA were lower compared to the analyzed cheeses and cheese-like products (Table 3 ).

\section{Conclusions}

The conducted study demonstrated that smoked and unsmoked cheeses and smoked and unsmoked cheese-like products were characterized by various contents of fatty acids and various lipid quality indices.

In smoked cheeses were significantly higher contents of SCFA and significantly lower contents of SFA than in unsmoked cheeses. The contents of MUFA and PUFA in cheeses were at similar levels. 
Although the smoked and the unsmoked cheeses contained significantly higher SFA and significantly lower MUFA and PUFA than the smoked and the unsmoked cheese-like products, they appear to be more beneficial to consumer health, because they have a higher level of SCFA, branched fatty acids (BCFA), vaccenic acid (VA), and conjugated linoleic acid cis9trans11 C18:2 (CLA).

Author Contributions: Had the original idea for the study and wrote the manuscript and conducted the statistical analysis, B.P.; collected and analyzed the data, B.P. and M.P.-S.; contributed in the writing of the section "Analytical methods", J.Ł. All authors have read and agreed to the published version of the manuscript.

Funding: This study was financed by Project financially supported by Minister of Science and Higher Education in the range of the program entitled "Regional Initiative of Excellence" for the years 2019-2022, Project No. 010/RID/2018/19, amount of funding 12.000.000 PLN.

Conflicts of Interest: The authors declare that there is no conflict of interests.

\section{References}

1. Grummer, R.R. Effect of feed on the composition of milk fat. J. Dairy Sci. 1991, 74, 3244-3257. [CrossRef]

2. Månsson, H.L. Fatty acids in bovine milk fat. Food Nutr. Res. 2008, 52. [CrossRef]

3. Simopoulos, A.P. The importance of the ratio of omega-6/omega-3 essential fatty acids. Biomed. Pharm. 2002, 56, 365-379. [CrossRef]

4. Bernard, L.; Bonnet, M.; Delavaud, C.; Delosiére, M.; Ferlay, A.; Fougére, H.; Graulet, B. Milk fat globule in ruminant: Major and minor compounds, nutritional regulation and differences among species. Eur. J. Lipid Sci. Technol. 2018, 102, 1-27. [CrossRef]

5. Ulbricht, T.L.V.; Southgate, D.A.T. Coronary heart disease: Seven dietary factors. Lancet 1991, 338, $985-992$. [CrossRef]

6. Houston, M. The relationship of saturated fats and coronary heart disease: Fa(c)t or fiction? A commentary. Ther. Adv. Cardiovasc. Dis. 2018, 12, 33-37. [CrossRef]

7. Zhuang, P.; Cheng, L.; Wang, J.; Zhang, Y.; Jiao, J. Saturated fatty acid intake is associated with total mortality in a nationwide cohort study. J. Nutr. 2019, 149, 68-77. [CrossRef]

8. Unger, A.L.; Torres-Gonzalez, M.; Kraft, J. Dairy fat consumption and the risk of metabolic syndrome: An examination of the saturated fatty acids in dairy. Nutrients 2019, 11, 2200. [CrossRef]

9. Jensen, R.G. The composition of bovine milk lipids: January 1995 to December 2000. J. Dairy Sci. 2002, 85, 295-350. [CrossRef]

10. Kim, Y.; Je, Y. Dairy consumption and risk of metabolic syndrome: A meta-analysis. Diabet. Med. 2016, 33, 428-440. [CrossRef]

11. Haug, A.; Høstmark, A.T.; Harstad, O.M. Bovine milk in human nutrition-A review. Lipids Health Dis. 2007, 6, 1-16. [CrossRef] [PubMed]

12. Arnould, V.M.-R.; Soyeurt, H. Genetic variability of milk fatty acids. J. Appl. Genet. 2009, 50, 29-39. [CrossRef] [PubMed]

13. Williams, C.M. Dietary fatty acids and human health. Ann. Zootech. 2000, 49, 165-180. [CrossRef]

14. Mensink, R.P. Metabolic and health effects of isomeric fatty acids. Curr. Opin. Lipidol. 2005, 16, 27-30. [CrossRef] [PubMed]

15. Ascherio, A.; Willett, W.C. Health effects of trans fatty acids. Am. J. Clin. Nutr. 1997, 66 (Suppl), 1006S-1010S. [CrossRef]

16. Mensink, R.P.; Zock, P.L.; Kester, A.D.; Katan, M.B. Effects of dietary fatty acids and carbohydrates on the ratio of serum total to HDL cholesterol and on serum lipids and apolipoproteins: A meta-analysis of 60 controlled trials. Am. J. Clin. Nutr. 2003, 77, 1146-1155. [CrossRef]

17. Stender, S.; Dyerberg, J. Influence of trans fatty acids on health. Ann. Nutr. Metab. 2004, 48, 61-66. [CrossRef]

18. Willett, W.C.; Stampfer, M.J.; Manson, J.E.; Colditz, G.A.; Speizer, F.E.; Rosner, B.A.; Hennekens, M.D.; Willett, W.C.; Stampfer, G.A.; Colditz, G.A.; et al. Intake of trans fatty acids and risk of coronary heart disease among women. Lancet 1993, 341, 581-585. [CrossRef]

19. Ascherio, A.; Hennekens, C.H.; Buring, J.E.; Master, C.; Stampfer, M.J.; Willett, W.C. Trans-fatty acids intake and risk of myocardial infarction. Circulation 1994, 89, 94-101. [CrossRef] 
20. Pietinen, P.; Ascherio, A.; Korhonen, P.; Hartman, A.M.; Willett, W.C.; Albanes, D.; Virtamo, J. Intake of fatty acids and risk of coronary heart disease in a cohort of Finnish men. The Alpha-Tocopherol, Beta-Carotene Cancer Prevention Study. Am. J. Epidemiol. 1997, 145, 876-887. [CrossRef]

21. Mozaffarian, D.; Willett, W.C. Consumption of trans fats and estimated effects on coronary heart disease in Iran. Eur. J. Clin. Nutr. 2007, 61, 1004-1010. [CrossRef] [PubMed]

22. Eulitz, K.; Yurawecz, M.P.; Sehat, N.; Fritsche, J.; Roach, J.A.G.; Mossoba, M.M.; Kramer, J.K.G.; Adlof, R.O.; $\mathrm{Ku}, \mathrm{Y}$. Preparation, separation, and confirmation of the eight geometrical cis/trans conjugated linoleic acid isomers 8,10-through 11,13-18:2. Lipids 1999, 34, 873-877. [CrossRef] [PubMed]

23. Akalln, A.S.; Tokusoglu, Ö. A potential Anticarcinogenic Agent: Conjugated linoleic acid (CLA). Pak. J. Nutr. 2003, 2, 109-110. [CrossRef]

24. Parodi, P.W. Cow's milk fat components as potential anticarcinogenic agents. J. Nutr. 1997, 127, $1055-1060$. [CrossRef] [PubMed]

25. Parodi, P.W. Anti-cancer agents in milkfat. Aust. J. Dairy Technol. 2003, 58, 114-118.

26. Aydin, R. Conjugated linoleic acid: Structure, sources and biological properties. Turk. J. Vet. Anim. Sci. 2005, 29, 189-195.

27. Park, Y. Conjugated linoleic acid (CLA): Good or bad trans fat? J. Food Comp. Anal. 2009, 22, S4-S12. [CrossRef]

28. Kee, J.-I.; Ganesan, P.; Kwak, H.-S. Bioactive conjugated linoleic acid (CLA) in milk. Korean J. Food Sci. Anim. Resour. 2010, 30, 879-885. [CrossRef]

29. Lim, J.-N.; Oh, J.-J.; Wang, T.; Lee, J.-S.; Kim, S.-H.; Kim, Y.-H.; Lee, H.-G. trans-11 18:1 vaccenic acid (TVA) has a direct anti-carcinogenic effect on MCF-7 human mammary adenocarcinoma cells. Nutrients 2014, 6, 627-636. [CrossRef]

30. Bachmann, H.P. Cheese analogues: A review. Int. Dairy J. 2001, 11, 505-515. [CrossRef]

31. Aljewicz, M.; Cichosz, G.; Kowalska, M. Cheese-like products, analogs of processed and ripened cheeses. Zywność Nauka Technol. Jakość 2011, 18, 16-25. [CrossRef]

32. Maga, J.A. Smoke in Food Processing; CRC Press: Boca Raton, FL, USA, 1988; p. 160.

33. Guillén, M.D.; Ibergoitia, M.L.; Sopelana, P.; Palencia, G. Components detected by headspace-solid phase microextraction in artisanal fresh goat's cheese smoked using dry prickly pear (Opuntia ficus indica). Lait 2004, 84, 385-397. [CrossRef]

34. Majcher, M.; Goderska, K.; Pikul, J.; Jeleń, H. Changes in volatile, sensory and microbial profiles during preparation of smoked ewe cheese. J. Sci. Food Agric. 2011, 91, 1416-1423. [CrossRef]

35. El-Tahra, M.A.A.; Ismail, M.M.; El-Metwally, R.I. Effect of adding smoke liquid or power to goat's milk on some characteristic of Domiatti cheese. Am. J. Food Sci. Nutr. Res. 2015, 2, 47-56.

36. Christie, W.W. (Ed.) The isolation of lipids from tissues. Recommended Procedures. Chloroform-methanol $(2: 1, v / v)$ extraction and "Folch" wash. In Lipid Analysis. Isolation, Separation, Identification and Structural Analysis of Lipids; Pergamon Press: Oxford, UK; New York, NY, USA; Toronto, ON, Canada; Tokyo, Japan; Sydney, Australia; Braunschweig, Germany, 1973; pp. 39-40.

37. ISO 15884:2002 (IDF 182:2002). Milkfat: Preparation of Fatty Acid Methyl Esters. Available online: https://www.iso.org/obp/ui/\#iso:std:iso:15884:ed-1:v1:en (accessed on 12 July 2003).

38. Osmari, E.K.; Cecato, U.; Macedo, F.A.F.; Souza, N.E. Nutritional quality indices of milk fat from goats on diets supplemented with different roughages. Small Rumin. Res. 2011, 98, 128-132. [CrossRef]

39. Ivanova, A.; Hadzhinikolova, L. Evaluation of nutritional quality of common carp (Cyprinus carpio L.) lipids through fatty acid ratios and lipid indices. Bulg. J. Agric. Sci. 2015, 21, 180-185.

40. Statistica, version 13.1; StatSoft: Kraków, Poland, 2007.

41. Rutkowska, J.; Sadowska, A.; Tabaszewska, M.; Stołyhwo, A. Fatty acid composition of hard cheeses from North, Eastern and central region of Poland. Bromat. Chem. Toksykol. 2009, 3, 263-269.

42. Zlatanos, S.; Laskardis, K.; Feist, C.; Sagredos, A. CLA content and fatty acid composition of Greek Feta and hard cheeses. Food Chem. 2002, 78, 471-477. [CrossRef]

43. Grega, T.; Sady, M.; Najgebauer, D.; Domagała, J.; Pustkowiak, H.; Faber, B. Seasonal changes in the level of conjugated linoleic acid (CLA) in ripened cheeses. Biotechnol. Anim. Husb. 2005, 21, 251-253. [CrossRef]

44. Talpur, F.N.; Bhanger, M.I.; Memon, N.N. Fatty acid composition with emphasis on conjugated linoleic acid (CLA) and cholesterol content of Pakistani dairy products. Pol. J. Food Nutr. Sci. 2008, 58, 313-320. 
45. Domagała, J.; Sady, M.; Grega, T.; Pustkowiak, H.; Florkiewicz, A. The influence of cheese type and fat extraction method on the content of conjugated linoleic acid. J. Food Comp. Anal. 2010, 23, 238-243. [CrossRef]

46. Paszczyk, B.; Polak-Śliwińska, M.; Łuczyńska, J. Fatty acid composition and trans isomers in cheeses and cheese-like products. Nauka Przyr. Technol. 2016, 10, 1-11. [CrossRef]

47. Kelsey, J.A.; Corl, B.A.; Collier, R.J.; Bauman, D.E. The effect of breed, parity, and stage of lactation on conjugated linoleic acid (CLA) in milk fat from dairy cows. J. Dairy Sci. 2003, 86, 2588-2597. [CrossRef]

48. Hanuš, O.; Krížová, L.; Samková, E.; Špička, J.; Kučera, J.; Klimešová, M.; Roubal, P.; Jedelská, R. The effect of cattle bread, season and type of diet on the fatty acid profile of raw milk. Arch. Anim. Breed. 2016, 59, 373-380. [CrossRef]

49. Zunong, M.; Hanada, M.; Aibibula, Y.; Okamato, M.; Tanaka, K. Variations in conjugated linoleic acid concentrations in cow's milk, depending on feeding systems in different seasons. Asian-Aust. J. Anim. Sci. 2008, 21, 1466-1472. [CrossRef]

50. Berry, R.; Hydamska, A.; Noto, A.; Kotyk, E.; Zahradka, P.; Taylor, C.G. Grazing period variations in cow milk vaccenic acid (VA) and conjugated linoleic acid (CLA). J. Nutr. Food Sci. 2012, 2, 1-7. [CrossRef]

51. Shantha, N.C.; Ram, L.N.; O'Leary, J.; Hicks, C.L.; Decker, E.A. Conjugated linoleic acid concentrations in dairy products as affected by processing and storage. J. Food Sci. 1995, 60, 695-697. [CrossRef]

52. Herzallah, S.M.; Al-Ismail, K.M.; Humeid, M.A. Influence of some heating and processing methods on fatty acid profile of milk and other dairy products. J. Food Agric. Environ. 2005, 3, 103-107.

53. Lobos-Ortega, I.; Revilla, I.; González-Martín, I.; Hernández-Hierro, J.M.; Vivar-Quintana, A.; González-Pérez, C. Conjugated linoleic acid contents in cheeses of different compositions during six month of ripening. Czech J. Food Sci. 2012, 30, 220-226. [CrossRef]

54. Luna, P.; De La Fuente, M.A.; Juárez, M. Conjugated linoleic acid in processed cheeses during the manu $\neg$ facturing stages. J. Agric. Food Chem. 2005, 53, 2690-2695. [CrossRef]

55. Zeppa, G.; Giordano, M.; Gerbi, V.; Arlorio, M. Fatty acid composition of Piedmont "Ossolano" cheese. Lait 2003, 82, 167-173. [CrossRef]

56. Ritvanen, T.; Putkonen, T.; Peltonen, K. A comparative study of the fatty acid composition of dairy products and margarines with reduced or substituted fat content. Food Nutr. Sci. 2012, 3, 1189-1196. [CrossRef]

57. Hanuš, O.; Samková, E.; Krížová, L.; Hasoňová, L.; Kala, R. Role of fatty acids in milk fat and the influence of selected factors on their variability-A Review. Molecules 2018, 23, 1636. [CrossRef] [PubMed]

58. Gómez-Cortés, P.; Juárez, M.; Angel de la Fuente, M. Milk fat acids and potential health benefits: An update vision. Trends Food Sci. Technol. 2018, 81, 1-9. [CrossRef]

59. Holub, D.J.; Holub, B.J. Omega-3 fatty acids from fish oils and cardiovascular disease. Mol. Cell. Biochem. 2004, 263, 217-225. [CrossRef]

60. Willett, W.C. The role of dietary $n-6$ fatty acids in the prevention of cardiovascular disease. J. Cardiovasc. Med. 2007, 8, S42-S45. [CrossRef] [PubMed]

61. Simopoulos, A.P. The importance of the omega-6/omega-3 fatty acid ratio in cardiovascular disease and other chronic diseases. Exp. Biol. Med. 2008, 233, 674-688. [CrossRef] [PubMed]

62. De Lorgeril, M.; Renaud, S.; Mamelle, N.; Salen, P.; Martin, J.L.; Monjaud, I.; Mamelle, N.; Martin, J.L.; Guidollet, J.; Touboul, P.; et al. Mediterranean alpha-linolenic acid-rich diet in secondary prevention of coronary heart disease. Lancet 1994, 343, s0140-s6736. [CrossRef]

63. Russo, G.L. Dietary $n-6$ and $n-3$ polyunsaturated fatty acids: From biochemistry to clinical implications in cardiovascular prevention. Biomed. Pharm. 2009, 77, 937-946. [CrossRef] [PubMed]

64. Simopoulos, A.P. Evolutionary aspects of diet, the omega-6/omega-3 ratio and genetic variation: Nutritional implications for chronic diseases. Biomed. Pharm. 2006, 60, 502-507. [CrossRef] [PubMed]

65. Dhiman, T.R.; Nam, S.-H.; Ure, M.L. Factors Affecting Conjugated Linoleic Acid Content in Milk and Meat. Crit. Rev. Food Sci. Nutr. 2005, 45, 463-482. [CrossRef] [PubMed]

66. Lock, A.L.; Parodi, P.W.; Bauman, D.E. The biology of trans fatty acids: Implications for human health and the dairy industry. Aust. J. Dairy Technol. 2005, 60, 134-142.

67. Shingfield, K.J.; Chilliard, Y.; Toivonen, P.; Kairenius, P.; Givens, D.I. Trans fatty acids and bioactive lipids in ruminant milk. Adv. Exp. Med. Biol. 2008, 606, 3-65. [CrossRef] [PubMed]

68. Ascherio, A.; Katan, M.B.; Zock, P.L.; Stampfer, M.J.; Willett, W.C. Trans fatty acids and coronary heart disease. N. Engl. J. Med. 1999, 340, 1994-1998. [CrossRef] [PubMed] 
69. Mozaffarian, D.; Katan, M.B.; Ascherio, A.; Stampfer, M.J.; Willett, W.C. Trans fatty acids and cardiovascular disease. N. Engl. J. Med. 2006, 354, 1601-1613. [CrossRef]

70. Dhaka, V.; Gulia, N.; Singh Ahlawat, K.; Singh Khatkar, B. Trans fat-sources, health risks and alternative approach-A review. J. Food Sci. Technol. 2011, 48, 534-541. [CrossRef]

71. Żegarska, Z.; Paszczyk, B.; Borejszo, Z. Conjugated linoleic acid (CLA) and trans C18:1 and C18:2 isomers in fat of some commercial dairy products. Pol. J. Nat. Sci. 2008, 23, 248-256. [CrossRef]

72. Collomb, M.; Schmid, A.; Sieber, R.; Wechsler, D.; Ryhanen, E.L. Conjugated linoleic acids in milk fat: Variation and physiological effects. Int. Dairy J. 2006, 16, 1347-1361. [CrossRef]

73. Chin, S.F.; Liu, W.; Storkson, J.M.; Ha, Y.L.; Pariza, M.W. Dietary sources of conjugated dienoic isomers of linoleic acid, a newly recognized class of anticarcinogens. J. Food Compos. Anal. 1992, 5, 185-197. [CrossRef]

74. Gutiérrez, L.F. Conjugated linoleic acid in milk and fermented milks: Variation and effects of the technological processes. Vitae 2016, 23, 134-145. [CrossRef]

(C) 2019 by the authors. Licensee MDPI, Basel, Switzerland. This article is an open access article distributed under the terms and conditions of the Creative Commons Attribution (CC BY) license (http://creativecommons.org/licenses/by/4.0/). 